\title{
Earlier multidisciplinary palliative care intervention for people with lung cancer: a systematic review and meta-analysis
}

\author{
Slavica Kochovska ${ }^{1}$, Diana H. Ferreira ${ }^{2}$, Tim Luckett ${ }^{1}$, Jane L. Phillips ${ }^{1}$, David C. Currow ${ }^{1,3}$ \\ ${ }^{1}$ IMPACCT, Faculty of Health, University of Technology Sydney, Sydney, NSW, Australia; ${ }^{2}$ Discipline Palliative and Supportive Services, Flinders \\ University, Adelaide, SA, Australia; ${ }^{3}$ Wolfson Palliative Care Research Centre, University of Hull, Hull, UK \\ Contributions: (I) Conception and design: All authors; (II) Administrative support: None; (III) Provision of study materials or patients: None; (IV) \\ Collection and assembly of data: All authors; (V) Data analysis and interpretation: All authors; (VI) Manuscript writing: All authors; (VII) Final \\ approval of manuscript: All authors. \\ Correspondence to: Prof. David C. Currow, BMed, MPH, PhD, FRACP, FAHMS. IMPACCT, Faculty of Health, University of Technology Sydney, \\ PO Box 123 Ultimo, New South Wales 2007, Australia. Email: david.currow@uts.edu.au.
}

\begin{abstract}
Lung cancer is the most common cancer and leading cause of cancer mortality globally. Lung cancer is associated with significant morbidity, with symptoms often being poorly managed, causing significant symptom burden for both patients and their family caregivers. In people with life-limiting illnesses including advanced cancer, palliative care has been effective in improving symptom control, physical and mental wellbeing, quality of life, and survivorship; with benefits extending to caregivers while in the role and subsequently. Earlier integration of palliative care within oncology may be associated with improved patient outcomes, and has been supported by two Lancet commissions and national guidelines. The evidence for its effectiveness, however, has been mixed across the cancer spectrum. The aim of this review was to evaluate the current evidence for the effectiveness of early integrated palliative care in improving outcomes for people with lung cancer and their caregivers. Meta-analyses were performed where studies used the same measure. Otherwise, synthesis used a narrative approach. Similar to other types of advanced cancer, this review reveals mixed evidence for the effectiveness of early referral to palliative care and for the effectiveness of individual palliative interventions for people with lung cancer and their caregivers. Evidence that on-demand palliative care is equally, if not more effective than palliative care that is routinely provided, raises the question whether initiation and provision of palliative care as part of multidisciplinary lung cancer care ought to be guided by an early referral or need-based referral. Better understanding of what constitutes palliative care when delivered to people with lung cancer and their caregivers will help delineate the correlation with reported outcomes for these populations.
\end{abstract}

Keywords: Lung cancer; palliative care; supportive care; multidisciplinary care

Submitted Sep 12, 2019. Accepted for publication Dec 12, 2019.

doi: $10.21037 /$ tlcr.2019.12.18

View this article at: http://dx.doi.org/10.21037/tlcr.2019.12.18

\section{Introduction}

Globally, lung cancer is the most common cancer (2.09 million cases) and the leading cause of cancer mortality (1.76 million deaths) (1). In Australia lung cancer remains the leading cause of cancer mortality, accounting for nearly 1 in 5 (18\%) cancer deaths, for both sexes (1 in 20 for males and 1 in 30 for females) before the age of 85 (2).
Lung cancer is associated with the highest proportion of cancer burden and a poor 5 -year survival rate of $17 \%$ (range, $68 \%$ stage I-3.2\% for stage IV) (3), which is comparatively lower than other cancers (2). In 2016 to 2017, lung cancer was the second most common reason for a radiotherapy course (in both males and females) and the second most common type of cancer for palliative care hospitalization (13\% of all cases) in Australia (2). Lung cancer is categorized 
as non-small cell lung cancer in more than $80 \%$ of cases and small cell lung cancer in about $15 \%$ of cases (3).

Lung cancer is associated with significant morbidity, with the most distressing symptoms commonly reported by people including breathlessness, pain, fatigue, and anorexia $(4,5)$. Symptoms experienced by people with lung cancer are often poorly managed, causing significant symptom burden. Effectively managing these physical and psychosocial symptoms (6), which also affect caregivers (7), requires the input of a multidisciplinary team, including specialist palliative care. Specialist palliative care (at home or the hospital) has been shown to be associated with improved pain and symptom control, anxiety and reduced hospital admissions for people with advanced cancer (8), with benefits extending to caregivers while in the role and subsequently (9). There is limited evidence of its effectiveness on people's quality of life, experience of care and economic cost (10).

The past few decades have seen a paradigm shift towards the provision of palliative care as integral to comprehensive care for people with advanced cancer. Earlier integration of palliative care within the oncology setting may be associated with improved patient outcomes $(4,11,12)$. In a landmark study in 2010, Temel and colleagues (13) showed that early integration of palliative care reduced depression and symptom burden, and improved quality of life for people newly diagnosed with metastatic non-small cell lung cancer. Subsequently, two Lancet commissions have made recommendations for palliative care to be offered from the earliest stages in the disease trajectory, and concurrently with any curative and/or life-prolonging therapies $(14,15)$. Earlier integration of palliative care into oncology care is also supported by national guidelines, including the American Society of Clinical Oncology (ASCO) Provisional Clinical Opinion (16) and the National Comprehensive Cancer Network (NCCN) Clinical Practice Guidelines in Oncology (17).

A recent systematic review reported mixed results for the effectiveness of early palliative care both in the outpatient and community setting, across various conditions (18). While some randomized controlled trials (RCTs) reported improvements (including improved depression, patient and caregiver quality of life, caregiver burden; increased use of advance care directives, patient and family satisfaction; reduced aggressive end-of-life care, hospitalizations, hospital length of stay, and medical care costs), other RCTs reported no evidence of improvement (in symptoms, quality of life and resource utilization and costs), when compared to "usual" care (18). Given the heterogeneity in patient populations, it is important to identify the sub-populations who would most benefit from early palliative care as part of their lung cancer care.

The aim of this review is to appraise the current evidence for the effectiveness of early integrated palliative care in improving outcomes for people with advanced (metastatic) lung cancer and their caregivers.

\section{Methods}

A systematic review conducted and reported according to the Preferred Reporting Items for Systematic Reviews and Meta-Analysis (PRISMA) guidelines (19). We reviewed studies reporting on the effectiveness of palliative care interventions provided to adult patients ( $\geq 18$ years) with advanced (metastatic) small cell lung cancer (SCLC) or non-small cell lung cancer (NSCLC). Studies with mixed cancer cohorts were eligible for inclusion if they included participants with lung cancer clearly delineated in their sample size. Included studies were reports on phase II and phase III randomized controlled health service trials (RCTs) examining either (I) the efficacy of integrating early specialized palliative care alongside standard oncology care versus standard oncology care alone; or (II) providing individual palliative care interventions simultaneously with oncology care, for any outcome of interest. Secondary analyses and qualitative findings of RCTs were excluded, as were published protocols. Systematic reviews were also excluded, with primary studies screened for eligibility.

MEDLINE and PubMed were searched for primary studies published between 1 January 2010 and 31 July 2019, using Medical Subject Headings (MeSH) terms and text words for 'lung cancer' AND 'palliative care' OR 'supportive care' AND 'randomized controlled trials', limited to English. Database searches used the CareSearch palliative care filter $(20,21)$. Database searching was supplemented with lateral searching of Google Scholar. Search results were imported into EndNote X9, and eligibility criteria applied to title/abstract screening and full text review (performed by S.K., in discussion with D.C.C.).

Data were extracted using an Excel proforma (Microsoft Office 2016) on: author, year, country, study design, sample (cancer stage; sample size), intervention/control, outcome measures, results, and author-identified conclusions. Intervention data were extracted using the Template for Intervention Description and Replication (TIDieR) checklist (22). 


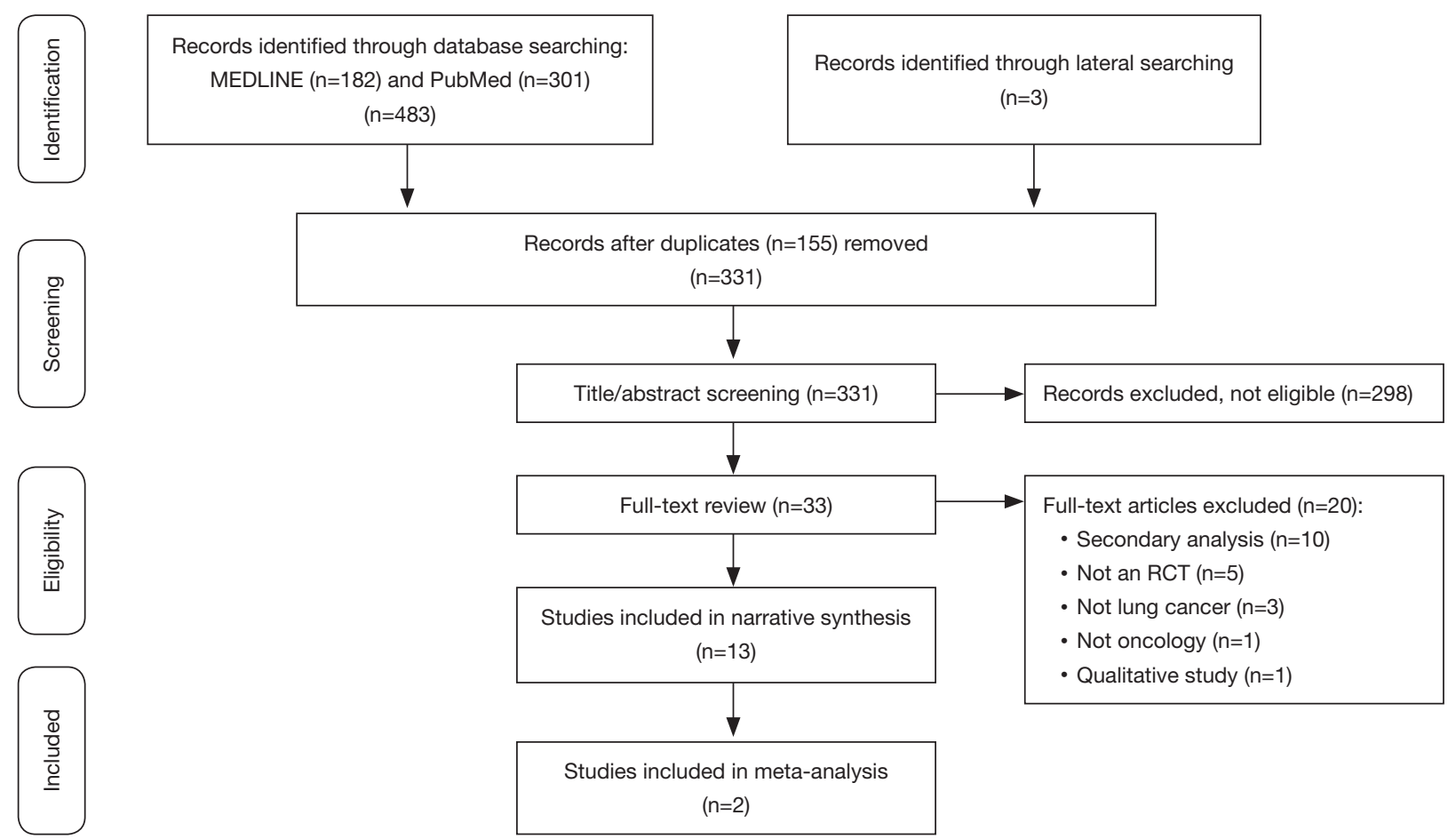

Figure 1 PRISMA flow diagram of included and excluded studies.

Synthesis used meta-analysis where results for the same outcome measure were reported in comparable ways in two or more trials. Random effects models were used to allow for the possibility that between-group differences varied according to differences in sample characteristics (23). Summary measures were mean differences in scores on the outcome measures between groups. These were estimated as change from baseline wherever possible, or else at follow-up only where the former was not reported. Ninetyfive percent confidence intervals (CIs) were estimated. Heterogeneity was estimated using the Cochrane $\mathrm{I}^{2}$ statistic, and interpreted according to the Cochrane Handbook of Systematic Reviews as follows: $0 \%$ to $40 \%$ unimportant, $30 \%$ to $60 \%$ moderate, $50 \%$ to $90 \%$ : substantial, and $75 \%$ to $100 \%$ considerable heterogeneity (24).

For outcomes where meta-analysis was not possible, synthesis used narrative methods (25) grouped around the type of intervention, and patient and caregiver outcomes, defined in the broadest sense.

\section{Results}

Of 485 records identified, 13 papers were included in the final analysis, reporting on 11 randomized controlled trials (RCTs) (Figure 1). Six RCTs, reported in the eight papers presented in Table S1, evaluated the effectiveness of delivering specialized palliative care alongside standard oncology care $v s$. standard oncology care alone $(13,26-32)$ (Table S1). Two of these trials $(27,30)$ reported their patient $(27,30)$ and caregiver $(28,31)$ outcomes separately, and are presented as such in Table S1. Five RCTs (33-37) evaluated the effectiveness of providing individual palliative care interventions simultaneously with oncology care (Table S2). All 11 trials were included in a narrative synthesis, but the heterogeneity of measures and the ways in which these were reported limited meta-analysis to two trials $(26,27)$.

\section{Study characteristics}

All eleven trials were conducted in high income countries, with the majority conducted in the United States $(\mathrm{n}=5)$ $(13,26-28,30,31,36)$, and the reminder conducted in Australia (37), Canada (32), Denmark (29), Singapore (34), Switzerland (33), and The Netherlands (35). Seven trials included people with various cancers (26-33,37), while four trials included lung cancer only (13,34-36). Four trials included people with cancer ('patients') and their family caregivers ('caregivers') $(27,28,30,31,35,36)$ and seven trials 
included patients only $(13,26,29,32-34,37)$.

Primary and secondary outcomes varied widely across studies, with the most common being quality of life and psychological symptoms (such as anxiety and depression). Others included symptom distress, functional status, and survivorship. For lung cancer specifically, the outcomes measured included: patient/caregiver quality of life and mood (including anxiety and depression); patient understanding of prognosis; patient-oncologist communication; aggressiveness of care at the end-oflife, patient resuscitation preferences, and survivorship $(13,27,28)$.

The components of early palliative care interventions in the eight RCTs that evaluated the effectiveness of delivering specialized palliative care alongside standard oncology care compared to usual oncology care alone $(13,26-32)$ were quite similar (Table S3). Overall, early referral interventions involved consultations with a specialist palliative care team (with various members) or palliative care physician or an advance practice nurse. Delivery was in person (in clinics or at home) or over the phone. Interventions were delivered: within 4 weeks of enrolment and at least monthly until death $(27,28)$; within 3 weeks after recruitment and at least monthly until death (13); tailored to patient need (29); within 30-60 days after diagnosis (early intervention) or 3 months after diagnosis (delayed intervention) (30,31); within 24 hours of diagnosis followed by phone and inperson contacts (26); within 1 month of recruitment followed by a routine phone call one week after the initial consultations and thereafter as needed, as well as a monthly outpatient palliative care follow up (32).

\section{Synthesis of results}

Effectiveness of providing specialized palliative care alongside standard oncology care $v s$. standard oncology care alone

\section{Patients}

\section{(I) Survival}

Survival data for early palliative care were drawn from two studies, one specifically evaluating outcomes in lung cancer (13), the other evaluating outcomes in a number of cancer populations including lung cancer (30). Compared to usual oncology care, early palliative care was associated with less premature mortality in people newly diagnosed with lung cancer (13). Longer one year survival was reported for people with advanced cancer (including lung cancer) for whom palliative care was initiated within 30 to 60 days of diagnosis, compared to those who received palliative care 3 months after their diagnosis ( $63 \%$ vs. $48 \%$; difference, $15 \% ; \mathrm{P}=0.038)(30)$.

\section{(II) Quality of life}

Quality of life was an outcome of interest in three studies, including two which evaluated this in patients with metastatic/ incurable lung cancer $(13,27)$ and one which evaluated this in patients with advanced cancer prognosis including lung cancer (32). Early palliative care was associated with improved quality of life at 24 weeks, but not at 12 weeks (27). For people with lung cancer specifically, quality of life improved at week 12 and 24 for the intervention group but deteriorated for the control group (27). Compared to usual oncology care, early palliative care was found to improve quality of life for people newly diagnosed with lung cancer (13). Similar findings have been replicated in another trial which found that early palliative care improved quality of life and satisfaction with care for people with advanced lung cancer (32).

\section{(III) Treatment and health care utilization}

Four studies evaluated the effect of early palliative care on treatment preferences and health care utilization, in lung cancer (13) and mixed-cancer populations (27,30,32). Early referral to palliative care appeared to impact on the patient-treating clinician relationship, with people in the intervention group (compared to usual care) more likely to discuss their wishes with their oncologists if they were dying (27) and having less aggressive treatment at the end of life (13). However, another trial found that early palliative care did not change the issues discussed during medical interactions (32). For people with advanced cancer receiving palliative care early (within 30-60 days after diagnosis) or later (3 months after diagnosis), similar relative rates between the two groups were reported for hospital and intensive care unit days, emergency department visits, chemotherapy in the last 14 days, and home deaths (30).

\section{(IV) Depression}

Two studies with focus on lung cancer evaluated the impact of early palliative care on depression $(13,27)$. Early palliative care was found to lower depression at 12 weeks (27). For people with lung cancer in particular, depression improved at week 12 and 24 when receiving early palliative care but deteriorated for those receiving usual oncology care only (27). Another trial reported fewer depressive symptoms for people in the intervention group receiving early palliative care (13).

A meta-analysis could be conducted for the Patient Health Questionnaire 9 (PHQ-9) (38) used in two studies 


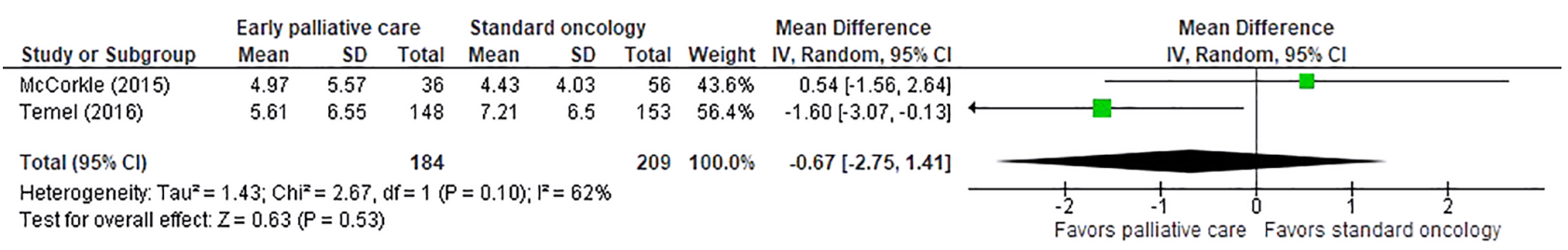

Figure 2 Results from meta-analysis of Patient Health Questionnaire 9 (PHQ-9) used in two studies comparing early palliative care alongside oncology care versus standard oncology alone.

(26,27). PHQ-9 measures depression on a nine-item scale, with higher scores indicating greater depression. Scores could be converted into five ordinal descriptors of depression. Results from these two studies found a nonsignificant difference between early palliative care versus standard oncology $(\mathrm{P}=0.53)$; however, heterogeneity was substantial (Figure 2).

\section{(V) Other symptoms}

Symptom outcomes were measured in four studies evaluating the effectiveness of early palliative care compared to standard oncology care $(29,32)$ or enhanced usual oncology care (26) or delayed palliative care (30). Patientreported outcomes (symptom impact, mood) were not statistically significant for people with advanced cancer (including lung cancer) receiving early palliative care (within 30 to 60 days of diagnosis) vs. delayed palliative care (3 months after diagnosis) (30). For people with advanced lung cancers, early intervention did not improve symptom and emotional distress, and personal and social dependency (26) or reduce symptom severity (32). Early specialist palliative care did not improve patients' primary needs (where the primary need was the patient-identified symptom or problem with highest intensity, including physical function, role function, emotional function, pain, nausea/vomiting, breathlessness, and lack of appetite) (29). In another trial, physical and emotional symptoms either remained stable or improved slightly for both the early intervention and usual care group (26).

\section{(VI) Self-efficacy}

Self-efficacy was a secondary outcome in one study evaluating the effects of multidisciplinary palliative care compared to enhanced usual care (26). For people with incurable (lung) cancer, personal competence (comprised of six daily living activities: eating, dressing, walking, traveling, bathing, and toileting) improved in both early palliative care intervention and usual care groups, while social competence (comprised of activities in the home, work activities, social and recreational roles, and communication) improved in the usual care group only (26). Perceptions of own health over time worsened for both groups (26). Enhanced usual care significantly improved self-efficacy and reduced uncertainty at 1 and 3 months (compared to the intervention) (26).

\section{(VII) Communication}

For people with advanced cancers (various), early involvement of specialist palliative care was not effective in improving medical interactions (32). However, people receiving early palliative care (compared to usual oncology care) were more likely to discuss their wishes with their oncologists if they were dying (27).

\section{Caregivers}

Early palliative care for people with lung cancer was effective in improving caregivers' total distress and depression, but not anxiety or overall quality of life at 12 weeks (28). No differences in caregivers' psychological and quality of life outcomes were observed at 24 weeks (28). Caregivers reported significantly lower depression and anxiety at 3 and 6 months before the death of the person with cancer; again, no such difference was reported for overall quality of life (28). For caregivers of people with advanced cancer (including lung cancer), early $v$ s. delayed palliative care improved depression and stress burden in the terminal analysis; there were no differences in quality of life or burden for either group (31).

\section{Effectiveness of providing individual palliative care interventions simultaneously with oncology care Patients \\ (I) Quality of life}

In people with metastatic or locally advanced lung or gastrointestinal cancers, an interventional program of nutrition and physical exercise did not improve overall healthrelated quality of life compared to usual care (33). In mixed patient populations (including people with lung cancer), a nurse-directed face-to-face educational intervention resulted in no significant difference between intervention and control groups in quality of life at 12 weeks after baseline (34). 
In people with inoperable lung cancer (predominantly non-small cell lung cancer), consultations and systematic needs assessment as part of patient's multidisciplinary team meetings ( $v s$. usual care where no such systematic assessment was provided at multidisciplinary team meetings) did not improve quality of life (37).

\section{(II) Other symptoms}

Nutrition and physical exercise (compared to usual care) reduced nausea and vomiting $(\mathrm{P}=0.023)$ and increased protein intake $(\mathrm{P}=0.01)$ (33). Compared to usual care, no statistical differences were found for energy intake, nutritional status and physical performance (33). A nursedirected face-to-face educational intervention resulted in no significant difference between intervention and control groups in mood at 12 weeks after baseline (34). Providing systematic needs assessment during consultations and multidisciplinary team meetings ( $v s$. usual care where no such systematic assessment was provided) found no improvement in unmet needs assessment, psychological morbidity or distress (37). Change score analysis indicated a relative benefit from the intervention for unmet symptom needs at week 8 and 12 post-assessment (effect size $=0.55$ and 0.40 , respectively) (37).

\section{(II) Communication}

All patients undertaking a nurse-directed face-to-face educational intervention reported satisfaction with the topics of discussion (including symptom management, problem solving, communication, and advance care planning), finding them useful (34).

\section{Caregivers}

Providing mindfulness-based stress reduction training to people with lung cancer, found no effect on their caregivers' psychosocial distress (including quality of life, mindfulness skills, self-compassion and rumination) (35). Offering telephone symptom management (TSM) (with cognitive-behavioral and emotion-focused therapy content) $v s$. education/support found no significant group differences in improving the caregiver self-efficacy for helping the person with lung cancer manage cancer symptoms as well as caregiver burden at 2 and 6 weeks post-intervention (36). A small improvement favoring TSM was observed in caregivers' self-efficacy to manage their own emotions and perceived social constraints from the patient, but no significant changes were reported over time for either group (36).

\section{Discussion}

There is mixed evidence for the effectiveness of early referral to palliative care and individual palliative care interventions for people with lung cancer and their caregivers. The two major positive trials testing the effectiveness of early referral to palliative care focused on lung cancer $(13,27)$. It is noteworthy that these trials were conducted at a single US site and in a country where concurrent palliative care and active oncology treatment has only recently been funded (39). All other trials were conducted with heterogeneous advanced cancer populations, at single or multiple centers, and some were conducted in countries where universal health care may also be available. The trials evaluating individual interventions were predominantly conducted at single sites, in countries with and without universal health care coverage. Four of the five trials focused exclusively on lung cancer. Their results were equally inconclusive in relation to the effectiveness of the proposed palliative care interventions.

This lack of conclusive evidence for lung cancer parallels findings for the effectiveness of early referral to palliative care in other cancer populations. Trials reporting advantages of providing early referral to palliative care include people newly diagnosed with gastrointestinal (GI; non-colorectal) cancer, where early referral decreased depression, improved patients' quality of life and ability to cope with the prognosis, and enhanced patient-clinician communication about end-of-life preferences (27). Importantly, the trial reported that quality of life and mood at week 12 improved for both the intervention and control groups (27). Breathlessness support services were found to improve mastery of breathlessness in people with advanced diseases, including lung cancer (40). Early integration of palliative care also improved survival (at 6 months and overall), but only for people with chronic obstructive and pulmonary disease (COPD) and interstitial lung disease, and not those with lung cancer (40).

Mixed results or lack of improvement within trials have also been noted. In people with gastric cancer, systematic early palliative care (compared to on-demand palliative care) showed slight, but not significant benefit in improving quality of life; and no improvement in anxiety/depression and family satisfaction with care (41). Similarly, people with advanced pancreatic cancer receiving systematic ( $v s$. on-demand) palliative care reported improved quality of life and symptom burden, and reduced hospitalization; but not overall survival (42). Early specialist palliative care compared to standard oncology care in people with malignant pleural mesothelioma (a cancer with high symptom burden and poor survival) did not improve quality 
of life nor psychological symptoms (depression and anxiety), suggesting that routine referral to specialist palliative care soon after diagnosis is not needed if access to such services can be provided when needed (43).

The same mixed benefits of integrating early palliative care in standard oncology care extends to caregivers. In gastrointestinal (non-colorectal) cancer, early palliative care was associated with improved caregiver total distress and depression, but not anxiety at 12 weeks (28). Although the same benefits were not observed at 24 weeks, significant benefits were observed for both depression and anxiety at 3 and 6 months before the patient's death (28).

Despite these limitations, earlier integration of palliative care into oncology care is supported by national guidelines, including for people newly diagnosis with people with nonsmall cell lung cancer (17). The recommendations further state that screening for palliative care needs should be continuous, at appropriate intervals as clinically indicated (17).

\section{Defining the intervention elements and measuring fidelity}

Despite great excitement after the Temel et al. (13) trial, the demonstrated survival advantages have not been reproduced other than in another US trial conducted by Bakitas et al. (30). In determining the effects of palliative care on survivorship, it is worth asking if these trials observed increased survival in the intervention group or increased mortality in the group that did not get palliative care. It is possible that what has been observed in these trials is not improved survival but premature mortality in the control group who did not get access to palliative care (44). Given the (perceived or actual) benefits of palliative care for both patients and caregivers (during and after the caregiving period) (9,31), lack of access to palliative care is likely to increase the burden of the disease on people's lives, including their survivorship. Delineating these effects in future trials is important, yet challenging, and will have implications for the design of future studies, as well as our understanding of the true net effect of palliative care for the cancer population in general, and lung cancer in particular.

Another important consideration when determining the correlation between the effects observed in these trials and the active intervention is understanding what element(s) within palliative care make the most difference for participant's outcomes. The five trials included in this review testing individual palliative care interventions in the oncology setting (Table S3) integrated different therapeutic elements into their palliative care interventions. The use of mindfulness-based techniques was reported as a potentially helpful therapy to reduce patients' distress, which is supported by previous research in other populations with cancer (45). However, more robust data is required to draw definite conclusions. Evidence is still conflicting for other interventions such as nutrition and exercisebased programs (46). This is important given the adverse impact of cachexia and muscle wasting on quality of life, survivorship and caregiver distress. Most trials evaluate different interventions as part of a comprehensive palliative care model of care. Thus, it might be difficult to determine the relevance and impact of each component on the patient/ caregiver outcomes. Other factors [for example, who delivers palliative care, the oncologist or the palliative care specialist (4)] might also play a role.

Definitional issues are also relevant when trying to unpack the components of "early" palliative care. Lack of consensus around "early" palliative care (18) means that this is defined in relation to multiple entry points, and can include any of the following: initial consultation at time of diagnosis; being seen by a palliative care specialist less than 3 months after diagnosis of advanced cancer or greater than 3 months before death; at particular treatment time points specific to cancer type (for example, at the time of cisplatinum resistance for advanced ovarian cancer) (18). Early palliative care can also be tied to the presence of prognostic signs or symptoms; or defined in relation to the setting (e.g., outpatient $v$ s. inpatient) or duration of continuity before death $(>90,31-90,11-30,1-10$ days) (18). This variation will particularly be relevant in multi-site trials where local practices and models of care are likely to influence the components and delivery of the intervention and controlled arms (44).

Equally importantly, lack of consensus around what is best supportive care or usual/standard care means that often these are not clearly defined in trials (47). An international Delphi-consensus process identified four key domains of best supportive care in clinical trials: multi-disciplinary care; supportive care documentation; symptom assessment; and symptom management (48). Incorporating this in the design of the control (but also active) arm will have implications in how these trails are conducted and outcomes compared (44).

\section{Implications for the provision of multidisciplinary care in lung cancer}

If multidisciplinary care is the gold standard of optimal care 
for people with lung cancer, how does integrating early palliative care affect this model of care, if at all? Evidence suggest that multidisciplinary teams in lung cancer are effective in changing patient management, more so than in improving survival (for which there is limited evidence) $(49,50)$. If multidisciplinary care is the standard and if palliative care is part of multidisciplinary lung cancer care, are the benefits associated with its initiation associated with early referral as routine practice or based on individual patient and caregiver needs?

Although studies have shown that a delayed initiation of palliative care results in poorer outcomes for people with cancer (when compared to early initiation after diagnosis) (30), studies comparing systematic $v s$. needs-based palliative care show no significant differences in survival (42), quality of life, psychological symptoms and family satisfaction with care (41). This suggest that providing palliative care when required might achieve the same outcomes for patients and caregivers. On-demand palliative care may also be a more cost-effective option.

A key element of providing multidisciplinary palliative care is the inclusion of primary care providers as part of the multidisciplinary care teams. Of the included trials in this review, only one trial (29) involved general practitioners in the provision of palliative care and only as part of standard oncology care (i.e., the control arm, where specialist palliative care was the intervention arm). Perhaps significantly, providing early specialist palliative care in this trial showed no significant effect on the primary outcome (which was the patient's identified need), and no differences between the groups in relation to other patient-identified symptoms, including survivorship. None of the included trials in this review included primary care providers in their palliative care intervention. Facilitating the engagement of general practitioners in multidisciplinary care teams may provide benefit to patients and their caregivers as their palliative care needs would be supported in the environment in which they live (i.e., at home as opposed to the hospital). Supporting their involvement through evidence-based methods, such as case conferencing (51), could have the potential to add to the quality of clinical decision making within multidisciplinary teams (52), ultimately resulting in improved patient and caregiver outcomes.

\section{Strengths and limitations}

There are a number of strengths and limitations with this systematic review. Its strengths are having examined all of the data from the early palliative care trails and synthesized the results, a number of recommendations are made about current practice and future research. Its major limitation is that only two of the included trials had $\geq 50 \%$ of participants with lung cancer, while the others included participants with various cancers. The latter studies did not report the lung cancer data separately. Therefore, the results reported here reflect outcomes reported for all cancers making it difficult to know to what extend those findings can be generalized for lung cancer specifically. However, cancers with poor outcomes such as gastrointestinal were included, which makes for comparable outcomes. Variability in outcome measures and reporting reduced our capacity to synthesize results quantitatively.

\section{Conclusions}

Mixed results were found in the literature for the effectiveness of early referral and for specific components of supportive care for people with lung cancer and their caregivers, mirroring findings for other types of cancer. Combined with evidence that on-demand palliative care is equally, if not more effective than systematic palliative care, this raises the question of whether initiation and provision of palliative care as part of multidisciplinary lung cancer care should be guided by an early or need-based referral. Better understanding of the "active ingredients" of palliative care when delivered to people with lung cancer and their caregivers will help delineate the correlation with reported outcomes.

\section{Acknowledgments}

We would like to thank Ms. Maja Garcia, a Research Assistant with IMPACCT, University of Technology Sydney, for her kind assistance with the data extraction and in preparing this manuscript for publication.

Funding: This work was supported by discretionary funds held by the IMPACCT team.

\section{Footnote}

Provenance and Peer Review: This article was commissioned by the Guest Editor (Emily Stone) for the series "Lung Cancer Multidisciplinary Care" published in Translational Lung Cancer Research. The article was sent for external peer review organized by the Guest Editor and the editorial 
office.

Conflicts of Interest: All authors have completed the ICMJE uniform disclosure form (available at http://dx.doi. org/10.21037/tlcr.2019.12.18). The series "Lung Cancer Multidisciplinary Care" was commissioned by the editorial office without any funding or sponsorship. DC reports and is an unpaid advisory board member for Helsinn Pharmaceuticals. He is a paid consultant and receives payment for intellectual property with Mayne Pharma and is a consultant with Specialised Therapeutics Australia Pty. Ltd. The authors have no other conflicts of interest to declare.

Ethical Statement: The authors are accountable for all aspects of the work in ensuring that questions related to the accuracy or integrity of any part of the work are appropriately investigated and resolved.

Open Access Statement: This is an Open Access article distributed in accordance with the Creative Commons Attribution-NonCommercial-NoDerivs 4.0 International License (CC BY-NC-ND 4.0), which permits the noncommercial replication and distribution of the article with the strict proviso that no changes or edits are made and the original work is properly cited (including links to both the formal publication through the relevant DOI and the license). See: https://creativecommons.org/licenses/by-nc-nd/4.0/.

\section{References}

1. WHO. Cancer, https://www.who.int/news-room/factsheets/detail/cancer (2018, accessed 8 September 2019).

2. Australian Institute of Health and Welfare. Cancer in Australia 2019. Canberra: AIHW, 2019.

3. Cancer Council. Lung Cancer. Available online: https:// www.cancer.org.au/about-cancer/types-of-cancer/lungcancer.html (2019, accessed 8 September 2019).

4. Shin J and Temel J. Integrating palliative care: when and how? Curr Opin Pulm Med 2013;19:344-9.

5. Iyer S, Roughley A, Rider A, et al. The symptom burden of non-small cell lung cancer in the USA: a real-world cross-sectional study. Support Care Cancer 2014;22:181-7.

6. Lutz S, Norrell R, Bertucio C, et al. Symptom frequency and severity in patients with metastatic or locally recurrent lung cancer: a prospective study using the Lung Cancer Symptom Scale in a community hospital. J Palliat Med 2001;4:157-65.

7. Milbury K, Badr H, Fossella F, et al. Longitudinal associations between caregiver burden and patient and spouse distress in couples coping with lung cancer. Support Care Cancer 2013;21:2371-9.

8. Higginson IJ and Evans CJ. What is the evidence that palliative care teams improve outcomes for cancer patients and their families? The Cancer Journal 2010;16:423-35.

9. Abernethy AP, Currow DC, Fazekas BS, et al. Specialized palliative care services are associated with improved shortand long-term caregiver outcomes. Support Care Cancer 2008;16:585-97.

10. Zimmermann C, Riechelmann R, Krzyzanowska M, et al. Effectiveness of specialized palliative care: a systematic review. JAMA 2008;299:1698-709.

11. Greer JA, Jackson VA, Meier DE, et al. Early integration of palliative care services with standard oncology care for patients with advanced cancer. CA Cancer J Clin 2013;63:349-63.

12. Bauman JR, Temel JS. The integration of early palliative care with oncology care: the time has come for a new tradition. J Natl Compr Canc Netw 2014;12:1763-71.

13. Temel JS, Greer JA, Muzikansky A, et al. Early palliative care for patients with metastatic non-small-cell lung cancer. N Engl J Med 2010;363:733-42.

14. Kaasa S, Loge JH, Aapro M, et al. Integration of oncology and palliative care: a Lancet Oncology Commission. Lancet Oncol 2018;19:e588-653.

15. Knaul FM, Farmer PE, Krakauer EL, et al. Alleviating the access abyss in palliative care and pain reliefan imperative of universal health coverage: the Lancet Commission report. Lancet 2018;391:1391-454.

16. Smith TJ, Temin S, Alesi ER, et al. American Society of Clinical Oncology provisional clinical opinion: the integration of palliative care into standard oncology care. J Clin Oncol 2012;30:880-7.

17. Wood DE. National Comprehensive Cancer Network (NCCN) clinical practice guidelines for lung cancer screening. Thorac Surg Clin 2015;25:185-97.

18. Davis MP, Temel JS, Balboni T, et al. A review of the trials which examine early integration of outpatient and home palliative care for patients with serious illnesses. Ann Palliat Med 2015;4:99-121.

19. Moher D, Liberati A, Tetzlaff J, et al. Preferred reporting items for systematic reviews and meta-analyses: the PRISMA statement. Ann Intern Med 2009;151:264-9.

20. Sladek R, Tieman J, Fazekas BS, et al. Development of a subject search filter to find information relevant to palliative care in the general medical literature. J Med Libr Assoc 2006;94:394-401.

21. Sladek RM, Tieman J. Applying evidence in the real world: 
a case study in library and information practice. Health Info Libr J 2008;25:295-301.

22. Hoffmann TC, Glasziou PP, Boutron I, et al. Better reporting of interventions: template for intervention description and replication (TIDieR) checklist and guide. BMJ 2014;348:g1687.

23. Riley RD, Higgins JPT and Deeks JJ. Interpretation of random effects meta-analyses. BMJ 2011;342:d549.

24. Higgins JPT and Green S. Cochrane handbook for systematic reviews of interventions Version 5.1.0. Available online: www.handbook.cochrane.org. The Cochrane Collaboration, 2011.

25. Popay J, Roberts H, Sowden A, et al. Guidance on the conduct of narrative synthesis in systematic reviews. A Product from the ESRC Methods Programme 2006; Version 1: b92.

26. McCorkle R, Jeon S, Ercolano E, et al. An Advanced Practice Nurse Coordinated Multidisciplinary Intervention for Patients with Late-Stage Cancer: A Cluster Randomized Trial. J Palliat Med 2015;18:962-9.

27. Temel JS, Greer JA, El-Jawahri A, et al. Effects of early integrated palliative care in patients with lung and GI cancer: a randomized clinical trial. J Clin Oncol 2017;35:834-41.

28. El-Jawahri A, Greer JA, Pirl WF, et al. Effects of early integrated palliative care on caregivers of patients with lung and gastrointestinal cancer: a randomized clinical trial. Oncologist 2017;22:1528-34.

29. Groenvold M, Petersen MA, Damkier A, et al. Randomised clinical trial of early specialist palliative care plus standard care versus standard care alone in patients with advanced cancer: The Danish Palliative Care Trial. Palliat Med 2017;31:814-824.

30. Bakitas MA, Tosteson TD, Li Z, et al. Early versus delayed initiation of concurrent palliative oncology care: patient outcomes in the ENABLE III randomized controlled trial. J Clin Oncol 2015;33:1438-45.

31. Dionne-Odom JN, Azuero A, Lyons KD, et al. Benefits of early versus delayed palliative care to informal family caregivers of patients with advanced cancer: outcomes from the ENABLE III randomized controlled trial. J Clin Oncol 2015;33:1446-52.

32. Zimmermann C, Swami N, Krzyzanowska M, et al. Early palliative care for patients with advanced cancer: a clusterrandomised controlled trial. Lancet 2014;383:1721-30.

33. Uster A, Ruehlin M, Mey S, et al. Effects of nutrition and physical exercise intervention in palliative cancer patients: A randomized controlled trial. Clin Nutr 2018;37:1202-9.

34. Yang GM, Teo I, Neo SH, et al. Pilot Randomized Phase II Trial of the Enhancing Quality of Life in Patients (EQUIP) Intervention for Patients With Advanced Lung
Cancer. Am J Hosp Palliat Care 2018;35:1050-6.

35. Schellekens MPJ, van den Hurk DGM, Prins JB, et al. Mindfulness-based stress reduction added to care as usual for lung cancer patients and/or their partners: A multicentre randomized controlled trial. Psychooncology 2017;26:2118-26.

36. Mosher CE, Winger JG, Hanna N, et al. Randomized pilot trial of a telephone symptom management intervention for symptomatic lung cancer patients and their family caregivers. J Pain Symptom Manage 2016;52:469-82.

37. Schofield P, Ugalde A, Gough K, et al. A tailored, supportive care intervention using systematic assessment designed for people with inoperable lung cancer: a randomised controlled trial. Psychooncology 2013;22:2445-53.

38. Kroenke K, Spitzer RL, Williams JBW. The PHQ9: validity of a brief depression severity measure. J Gen Intern Med 2001;16:606-13.

39. Kamal AH, Currow DC, Ritchie CS, et al. Communitybased palliative care: the natural evolution for palliative care delivery in the US. J Pain Symptom Manage 2013;46:254-64.

40. Higginson IJ, Bausewein C, Reilly CC, et al. An integrated palliative and respiratory care service for patients with advanced disease and refractory breathlessness: a randomised controlled trial. Lancet Respir Med 2014;2:979-87.

41. Scarpi E, Dall'Agata M, Zagonel V, et al. Systematic vs. on-demand early palliative care in gastric cancer patients: a randomized clinical trial assessing patient and healthcare service outcomes. Support Care Cancer 2019;27:2425-34.

42. Maltoni M, Scarpi E, Dall'Agata M, et al. Systematic versus on-demand early palliative care: results from a multicentre, randomised clinical trial. Eur J Cancer 2016;65:61-8.

43. Brims F, Gunatilake S, Lawrie I, et al. Early specialist palliative care on quality of life for malignant pleural mesothelioma: a randomised controlled trial. Thorax 2019;74:354-61.

44. Currow DC, Foley K, Zafar SY, et al. The need for a reevaluation of best supportive care studies reported to date. Br J Cancer 2011;104:390-1.

45. Zainal NZ, Booth S and Huppert FA. The efficacy of mindfulness-based stress reduction on mental health of breast cancer patients: A meta-analysis. Psychooncology 2013;22:1457-65.

46. Rueda JR, Solà I, Pascual A, et al. Non-invasive interventions for improving well-being and quality of life in patients with lung cancer. Cochrane Database Syst Rev 2011;(9):CD004282.

47. Nipp RD, Currow DC, Cherny NI, et al. Best supportive care in clinical trials: review of the inconsistency in control 
arm design. Br J Cancer 2015;113:6.

48. Zafar SY, Currow DC, Cherny N, et al. Consensusbased standards for best supportive care in clinical trials in advanced cancer. Lancet Oncol 2012;13:e77-82.

49. Coory M, Gkolia P, Yang IA, et al. Systematic review of multidisciplinary teams in the management of lung cancer. Lung Cancer 2008;60:14-21.

50. Hong NJL, Wright FC, Gagliardi AR, et al. Examining the potential relationship between multidisciplinary cancer care and patient survival: an international literature review.
J Surg Oncol 2010;102:125-34.

51. Abernethy AP, Currow DC, Hunt R, et al. A pragmatic $2 \times 2 \times$ 2 factorial cluster randomized controlled trial of educational outreach visiting and case conferencing in palliative caremethodology of the Palliative Care Trial [ISRCTN 81117481]. Contemp Clin Trials 2006;27:83-100.

52. Lamb BW, Brown KF, Nagpal K, et al. Quality of care management decisions by multidisciplinary cancer teams: a systematic review. Ann Surg Oncol 2011;18:2116-25.

Cite this article as: Kochovska S, Ferreira DH, Luckett T, Phillips JL, Currow DC. Earlier multidisciplinary palliative care intervention for people with lung cancer: a systematic review and meta-analysis. Transl Lung Cancer Res 2020;9(4):1699-1709. doi: $10.21037 /$ tlcr.2019.12.18 
Table S1 Randomized controlled trials evaluating specialized palliative care interventions + standard oncology care $v s$ stand oncology care alone

\begin{tabular}{|c|c|c|c|c|}
\hline Author, year, country & Aim & Sample & Intervention & Control \\
\hline $\begin{array}{l}\text { El-Jawahri et al, } \\
2017 \text { (28), USA, non- } \\
\text { blinded randomized } \\
\text { trial, single site }\end{array}$ & $\begin{array}{l}\text { To evaluate the effects of } \\
\text { early integrated palliative } \\
\text { care on caregiver- } \\
\text { reported outcomes in } \\
\text { patients with newly } \\
\text { diagnosed incurable } \\
\text { cancers }\end{array}$ & $\begin{array}{l}\text { Caregivers of people with incurable lung } \\
\text { (NSCLC, SCLC, mesothelioma) or non- } \\
\text { colorectal gastrointestinal (GI) cancers: } \\
\text { total }(n=275) \text {; intervention }(n=137) \text {; control } \\
(n=138)\end{array}$ & $\begin{array}{l}\text { Early integrated palliative } \\
\text { care \& oncology care; } \\
\text { meeting with a PC clinician } \\
\text { at least once per month until } \\
\text { death }\end{array}$ & $\begin{array}{l}\text { Usual oncology } \\
\text { care }\end{array}$ \\
\hline
\end{tabular}

Outcome measures

Primary and Depression Scale (HADS)

Secondary - Caregiver mood and anxiety-HADS - Caregiver QOL-SF-36
- Patient mood and anxiety - Hospital Anxiety Outcomes
Groenvold et al., To investigate the 297 patients with stage IV cancer of any Early specialist palliative 2017 (29), Denmark, potential impact of ealy specialist palliative contriled th care in patients with advanced cancer and ype, or stage III/ $/ \mathrm{V}$ cancers in the cent nervous system (145 to intervention, 25\% in controm), (14\% in intervent) $25 \%$ in control), or the breast (21\% ancers in stage IV or cancers in the of grades III/V (26\% in intervention, $22 \%$ in control)

Temel et al., 2017 To evaluate the effects of $\boldsymbol{\bullet}$ People within 8 weeks of a diagnosis 27), USA, nontrial, single site

early integrated palls of . People within 8 weeks of a diagn care on patient-reported mesothelioma) or non-colorectal $G$ $\begin{array}{ll}\text { outcomes in patients } & \text { (pancreatic, esophageal, gastric or } \\ \text { hepatobiliary) cancer: total }(n=350) & \end{array}$

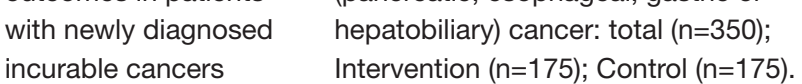
- Lung cancer: intervention ( $n=96,54.9 \%$ control $(n=95,54.3 \%)$. - Non-colorectal Gl cancer: interventio
$(\mathrm{n}=79,45.1 \%) ;$ control $(\mathrm{n}=80,45.7 \%)$ (30), USA, fast- of early vs. delayed $\begin{array}{ll}\text { track randomized } & \text { intervention timing } \\ \text { controlled trial, } & \text { on patient-reported }\end{array}$ on patient-reported

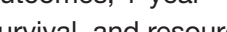

- Total $(n=207)$ : early intervention $(n=104)$ delayed intervention ( $\mathrm{n}=103)$ - Lung cancer: early group ( $\mathrm{n}=46,44.2 \%)$, delayed group $(n=42,40.8 \%)$ Gl tract: early group $(n=26,25 \%)$ - Breast: early group $(n=10,9.6 \%)$ delayed group ( $n=13,12.6 \%$ ) $9.6 \%)$, delayed group $(n=13,12.6 \%)$ - Hematologic malignancy: Early group
$(\mathrm{n}=5,4.8 \%)$, delayed group $(\mathrm{n}=5,4.8 \%)$

Dionne-Odom et al. To determine the effect 2015 (31), USA, fast- of early vs. delayed track randomized initiation of a palliative controlled trial, care intervention for family caregivers of
people with advanced people wit
cancer

- 122 caregivers (early group, $n=61$;
delayed group, $n=61$ ). ung (early group, $\mathrm{n}=28,45$. delayed group, $\mathrm{n}=25,41 \%$ ); Gastrointestinal (early group, $\mathrm{n}=14$ delayed group, $n=5,8.2 \%$ ) - Breast (early group, $n=5,8.2 \%$; delayed group, $n=5,8.2 \%$ ) Hematologic (early group, $n=3,4.9 \%$ delayed group, $n=4,6.6 \%$ ) - Other solid tumor (early group, $\mathrm{n}=\mathrm{a}$ $9.8 \%$; delayed group, $n=5,8.2 \%$ )

$\begin{array}{lll}\text { McCorkle et al. } & \text { To evaluate the effects } & \text { - Late-stage cancer diagnosis; post- } \\ \text { 2015 (26). USA, } & \text { of a multidisciplinary } & \text { biopsy or surgery with additional }\end{array}$ cluster-randomized intervention coordinated treatment recommended; at least controlled trial, four by advance practice self-reported chronic condition disease-specific nurses (APNs) on clinics at a single site patient-reported outcomes in patients newly diagnosed with
late-stage cancers Total ( $n=146)$ : intervention $(n=66$ control $(n=80)$ d to the intervention: gynecologic $(\mathrm{n}=20)$ and lung $(\mathrm{n}=16)$ clinics eck $(n=17)$ and gastrointestinal $(n=39)$

Multidisciplinary intervention
coordinated by an advanced practice nurse (APN)

Outpatient palliative care Delayed group after diagnosis - Caregiver Depressed mood - Center for Epidemiologic Study-Depression Scale (C ry-Borgatta CG Burden (MBCB) subscales

Standard care only. Primary

Change in patients primary need -7 of 15 departments of pain, dyspnea and lack of appetite Seconday ncology, general $•$ Changes in the seven QLQ-C30 scales ractitioners (GPs)

services

Usual oncology Primary

- QOL-Functional Assessment of Cancer Secondary - Mood and anxiety - Patient Health Paport of com Prognosis and Treatment Perceptions Questionnaire

Patients in the Q Quality of Life-46-item Functional Assessment of Chronic Illiness-TherapyLife (QUAL-E) Depression Scale (CES-D) - Resource use and location of dea

Enhanced usual
care group (usual multidisciplinary

care plus a

copy of the

symptom

toolkit with

Primary and secondary

- Functional status-Enforse

Self-rated health (physical and mental) -1 st

item of SF-12

- QOL-FACT-G) (version 4) 52 to control): cancer in the lung (39\% in intervention, $30 \%$ in control),

Bakitas et al., 2015 To compare the effect genitourinany (Early grow, $n=5,8 \%$

Improvement in caregivers to

IScale or QOL at week 12

Signifiont effects on cars outcomes at week 24

oth anxiety and depression

Zimmermann et al. cluster-randomized controlled trin
single site

To assess the effect of
early palliative care in patients with advance aspects of quality of

Advanced cancer prognosis 6-24 . Adrins. lung cancer $(n=101 ; 43,81 \%$ up in the oncology palliative (oncologist and breas $(n=72$ phe clinio by a palliative care oncology nurses) 13..3\%), gynecological $(n=71 ; 30.8 \%$ - Total $(n=461)[$
Control $(n=233)]$ Control $(n=233)]$. Lung cancer: total ( $n=101)$; interven

Temel et al. 2010 To examine the effect $\begin{array}{ll}\text { (13), USA, non- } & \text { of early palliative } \\ \text { blinded randomized } & \text { care integrated with }\end{array}$ $\begin{array}{ll}\text { blinded randomized } & \text { care integrated with } \\ \text { controlled trial, } & \text { standard oncologic c }\end{array}$ - People with metastatic, non-small cell lung cancer

: Intervention $(n=76)$

single center

outcomes, the use of health services, and the among patients with metastatic non-small cel lung cancer Caregiver Objective, stress, and demand care provided by function, emotional function, nausea/vomiting Questionnaire-9 (PHQ-9); HADS

Early specialist palliative care had no significant effect on the primary outcome over 8 weeks $(P=0.14)$

Deparace analyses of each of the seven scales showed no difierences vomiting, showing the largest change $(P=0.013,0.01$ threshold $)$ favoring the runion

列

Greater improvement in the intervention group in $\mathrm{QOL}$ baseline to -Improved QOL and depression at week 12 and 24 (patients with intervention) vs. deterioration in both (patients with lung cancer; usual care) - Improved QOL and mood by week 12 (patients with Gl cancers; both groups) their oncologist if they were dying $(30.2 \%$ vs. $14.5 \% ; \mathrm{P}=0.004)$

- There were no significant differences between the early palliative care and delayed groups in QOL, symptom impact and moon 3 months after enrolmen

ear (early group, $63 \%$ vs. delayed

Median survival was 18.3 months for the early group $(n=50)$ and 11.8 month 政 政 Use of chemotherapy in the last 2 weeks of life was not statistically different $(1.57 ; 95 \% \mathrm{Cl}, 0.37$ to $6.7 ; \mathrm{P}=0.54$

- There were no significant differences in the number of decedents who died home in the early $(n=27,54 \%)$ or delayed intervention $(n=28,47 \%)$

- The intervention led to lower depression in the early group compared to the The telephone based and delayed group (mean difference, $-3.4 ; \mathrm{SE}, 1.5 ; \mathrm{d}=-0.32 ; \mathrm{P}=0.02$ )

- There were no significant differences in $Q \mathrm{OL}$ (mean difference $=-2$; SE $=2.3 ; \mathrm{d}=-0.13 ; \mathrm{P}=-0.39$ ) or burden (objective burden: mean difference $=0.3$ E $=0.7, d=0.09, P=0.64$, stress burden. mean difference $=-0.5, \mathrm{SE}=0.5$; $P=0.97)$ compared with initition 3 months bter

Symptom distress-Symptom Distress Scale
(SDS) - Health distress-four-item scale developed by

- Anxiety-HADS

- Uncertainty-Mishel Uncertainty in IIInes

Scale-Community Form (MUIS-C)

- Self-efficacy-Self-Efficacy for Managin

Chronic Disease Scale (SEMCD

Primary and secondary

- QOL-Functional Assessment of Chronic liness $•$ No difference for FACIT-Sp:

Therapy Spiritual Well-Being (FACIT-Sp); QUALAssmom severty-Edmonton Symptom Assessment System (ESAS) FAMCARE-P16 (a) interaction Scale (CARES-MIS)

Primary

Consultation and follow-up Standard with palliative care physician/ oncologic care advance practice nurse; in the ambulatory setting (National Consensus Project for Quality Palliative Care)
No differences between the two groups on the primary patient-reported ( Both groups: significant improvement on personal competence Both groups: worse perceptions of their own health over time ( rom baseline for both groups

Overall, secondary outcomes remained stable within the groups; but better self-efficacy at 1 month $(P<0.0097)$ and less uncertainty at 1 month $(P<0.0007)$ and 3 months $(P<0.0 .106)$ compared to the intervention group - No difference in ESAS and CARES-MIS. At 4 months:

政 group

The intervention group showed

- Improved QOL TOI 6.0 (FACT-L mean score 98.0 vs. 91.5; P=0.03 and LCS 1.7) - Fewer depressive symptoms ( $16 \%$ vs. $38 \%$; $\mathrm{P}=0.01$ )

.

metastatic palliative cerl lod to significarty improvements in both quality of patients receiving standard care, patients receiving early palliative the end of life but longer survival quality of life was non-significan at the primary endpoint, this tria patients with advanced cancer
- Significant difference in QUAL-E and FAMCARE-P16 favoring the

diagnosed incurable cancers early integrated palliative care outcomes, with differential meated palliative care may be specific needs of each patient This study supports the allinive care and improved vival, but the mechanisms urther research

prentovision of this of this interve convenience ability to teach and foster scores (adjusted mean difference, $-1.17 ; 95 \% \mathrm{Cl},-2.33$ to $-0.01 ; \mathrm{P}=0.048$ ) in analyses of decedents' outcomes looking the Stanford Patient Education Research
- QOL-Trial Outcome Index (TOI); Functiona Assessment of Cancer Therapy-Lung (FACT-L): Secondary

- Anxiety and depression-HADS; PHQ-9

- Aggressive care at the end of life-

chemotherapy within 14 days before death; no

less before death hospice care; or admission to hospice 3 days or 
Table S2 Randomized controlled trials evaluating individual palliative care interventions $v s$ standard/usual oncology care

\begin{tabular}{|c|c|c|c|c|c|c|c|}
\hline Author, year, country & Aim & Sample & Intervention & Control & Outcome measures & Results & Conclusions \\
\hline $\begin{array}{l}\text { Uster et al. } 2018 \text { (33); } \\
\text { Switzerland; Two- } \\
\text { arm, parallel group, } \\
\text { randomized controlled } \\
\text { trial; single site }\end{array}$ & $\begin{array}{l}\text { To test the effects of a } \\
\text { combined nutrition and } \\
\text { physical exercise program } \\
\text { on cancer patients with } \\
\text { metastatic or locally } \\
\text { advanced tumors of the } \\
\text { gastrointestinal and lung } \\
\text { tracts }\end{array}$ & 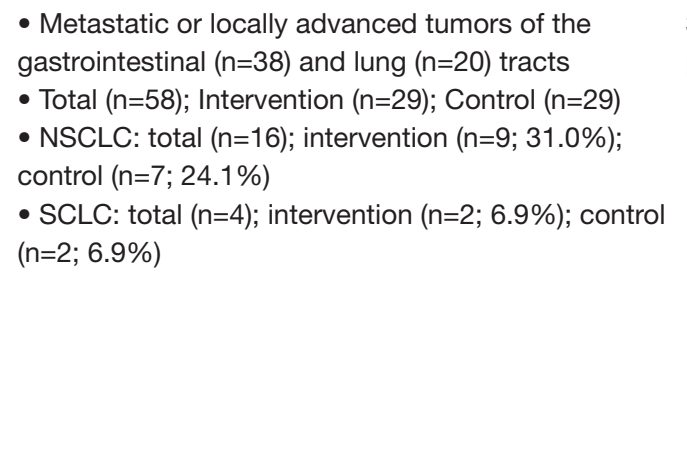 & $\begin{array}{l}3 \text { month nutrition and } \\
\text { physical exercise program }\end{array}$ & $\begin{array}{l}\text { Usual care (standard } \\
\text { oncology care; maintain } \\
\text { usual daily physical activity } \\
\text { level; nutritional support } \\
\text { provided only when medically } \\
\text { indicated) }\end{array}$ & $\begin{array}{l}\text { Primary } \\
\text { - QOL-European Organization for Research and } \\
\text { Treatment of Cancer Quality of Life Questionnaire V3.0 } \\
\text { (EORTC QLQ-C30) } \\
\text { Secondary } \\
\text { - Dietary intake-3 day food diaries) } \\
\text { - Nutritional status-body weight (bioelectrical impedance } \\
\text { analysis) } \\
\text { - Physical performance-handgrip strength, 6-min walk } \\
\text { and timed sit-to-stand test } \\
\text { - Clinical data- unplanned admission, total length of all } \\
\text { hospital stays, performance status (ECOG) }\end{array}$ & $\begin{array}{l}\text { - No difference in global health status/ } \\
\text { quality of life (overall QoL) post } \\
\text { intervention (improvement in both } \\
\text { groups) } \\
\text { - Reduced nausea and vomiting } \\
\text { (P=o.023) and increased protein intake } \\
\text { ( } P=0.01 \text { ) in the intervention group } \\
\text { - No statistical differences for energy } \\
\text { intake, nutritional status and physical } \\
\text { performance }\end{array}$ & $\begin{array}{l}\text { Good adherence to a } \\
\text { combined nutrition and } \\
\text { exercise program; the } \\
\text { multimodal intervention did } \\
\text { not improve overall QOL, but } \\
\text { contributed to an adequate } \\
\text { protein intake and to the } \\
\text { general well-being of the } \\
\text { patient by reducing nausea } \\
\text { and vomiting }\end{array}$ \\
\hline $\begin{array}{l}\text { Yang et al. } 2018 \text { (34); } \\
\text { Singapore; pilot, } \\
\text { randomized phase II trial; } \\
\text { single site }\end{array}$ & $\begin{array}{l}\text { To determine feasibility } \\
\text { and acceptability of the } \\
\text { Enhancing Quality of Life in } \\
\text { Patients (EQUUIP) intervention; } \\
\text { data completion rate of } \\
\text { patient reported outcome } \\
\text { measures in the trial; the } \\
\text { estimated effect of the EQUIP } \\
\text { intervention on quality of life } \\
\text { and mood }\end{array}$ & 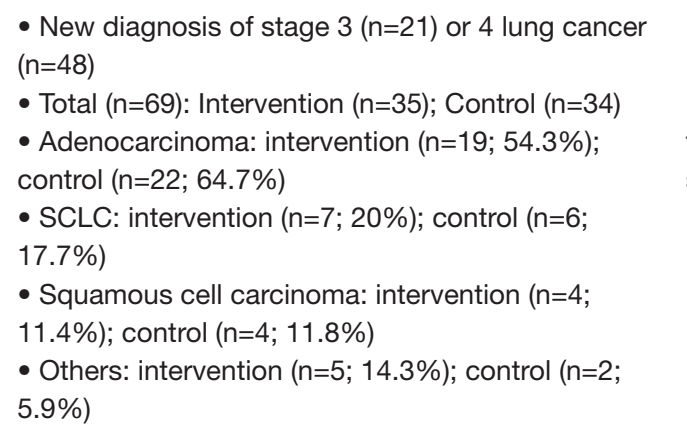 & $\begin{array}{l}\text { Usual care plus patients } \\
\text { individually received the } \\
\text { EQUIP intervention (4 } \\
\text { face-to-face educational } \\
\text { sessions with a nurse) }\end{array}$ & $\begin{array}{l}\text { Usual care (standard } \\
\text { oncology care as well } \\
\text { as referral for palliative } \\
\text { care services if deemed } \\
\text { appropriate by the primary } \\
\text { oncologist) }\end{array}$ & $\begin{array}{l}\text { Primary } \\
\text { - QOL-Chinese validated Functional Assessment of } \\
\text { Cancer Therapy-Lung (FACT-L); Lung Cancer Subscale } \\
\text { (LCS); Trial Outcome Index (TOI) } \\
\text { Secondary } \\
\text { - Mood-Chinese validated Hospital Anxiety and } \\
\text { Depression Scale (HADS) }\end{array}$ & $\begin{array}{l}\text { - No significant difference between } \\
\text { intervention and control groups in } \\
\text { quality of life and mood at } 12 \text { weeks } \\
\text { after baseline } \\
\text { - All patients were satisfied with the } \\
\text { topics shared and felt they were useful }\end{array}$ & $\begin{array}{l}\text { Nurse-directed face-to-face } \\
\text { educational sessions were } \\
\text { feasible and acceptable } \\
\text { to patients with advanced } \\
\text { lung cancer; however, there } \\
\text { was no indication of benefit } \\
\text { of the EQUUP intervention } \\
\text { on quality of life and mood } \\
\text { (which could be due in part to } \\
\text { a low prevalence of targeted } \\
\text { symptoms) }\end{array}$ \\
\hline $\begin{array}{l}\text { Schellekens et al. } 2017 \\
\text { (35); The Netherlands; } \\
\text { parallel group randomized } \\
\text { controlled trial; multi-site }\end{array}$ & $\begin{array}{l}\text { To examine the effectiveness } \\
\text { of mindfulness-based stress } \\
\text { reduction (MBSR) added } \\
\text { to care as usual (CAU) vs. } \\
\text { CAU alone in reducing } \\
\text { psychological distress in lung } \\
\text { cancer patients and/or their } \\
\text { partners }\end{array}$ & $\begin{array}{l}\text { - Patients and/or partners of patients presenting } \\
\text { with cytologically or histologically proven NSCLC } \\
\text { or SCLC. Both curative and palliative stage were } \\
\text { included, with stage being based on the intent of } \\
\text { the anticancer treatment } \\
\text { - Patients ( } n=63) \text { : CAU+MBSR ( } n=31) \text {; CAU (n=32) } \\
\text { - Caregivers ( } n=44) \text { : CAU+MBRS ( }(n=21) \text {; CAU } \\
\text { (n=23) } \\
\text { - NSCLC: intervention ( }(n=28 ; 90 \%) \text {; control ( } n=26 \text {; } \\
81 \%) \\
\text { - SCLC: intervention ( } n=2 ; 7 \%) \text {; control } \\
(n=5 ; 16 \%) \\
\text { Mesothelioma: intervention ( }(n=1 ; 3 \%) \text {; control } \\
(n=1 ; 3 \%)\end{array}$ & $\begin{array}{l}\text { Care as usual plus } \\
\text { mindfulness-based } \\
\text { stress reduction (group- } \\
\text { based training in which } \\
\text { participants practice } \\
\text { mindfulness and receive } \\
\text { teaching on stress) }\end{array}$ & Care as usual & $\begin{array}{l}\text { Primary } \\
\text { - Psychological distress-Hospital Anxiety and Depression } \\
\text { Scale (HADS) } \\
\text { Secondary } \\
\text { - QOL-EORTC QLQ-C30 } \\
\text { - Caregiver burden-Self-Perceived Pressure from } \\
\text { Informal Care } \\
\text { - Patient-caregiver relationship satisfaction (Investment } \\
\text { Model Scale-Satisfaction subscale) } \\
\text { - Mindfulness skills-Five Facet Mindfulness Questionnaire } \\
\text { - Self-compassion-Self-Compassion Scale } \\
\text { - Post-traumatic stress symptoms-Impact of Event Scale }\end{array}$ & $\begin{array}{l}- \text { Significantly less psychological } \\
\text { distress }(P=0.008, d=0.69) \text { in the } \\
\text { intervention than the control } \\
\text { - Baseline distress moderated outcome: } \\
\text { those with more distress benefitted } \\
\text { most from MBSR } \\
\text { - Patients showed more improvements } \\
\text { in quality of life, mindfulness skills, self- } \\
\text { compassion, and rumination in the } \\
\text { intervention than the control. In partners, } \\
\text { no differences were found between } \\
\text { groups }\end{array}$ & $\begin{array}{l}\text { Findings suggest that } \\
\text { psychological distress in } \\
\text { lung cancer patients can } \\
\text { be effectively treated with } \\
\text { MBSR; no effect was found } \\
\text { in partners (possibly because } \\
\text { they were more focused on } \\
\text { patients' well-being rather } \\
\text { than their own) }\end{array}$ \\
\hline $\begin{array}{l}\text { Mosher et al. } 2016 \text { (36); } \\
\text { USA; pilot randomized } \\
\text { trial; Single site }\end{array}$ & $\begin{array}{l}\text { To examine the preliminary } \\
\text { efficacy of telephone-based } \\
\text { symptom management (TSM) } \\
\text { for symptomatic lung cancer } \\
\text { patients and their family } \\
\text { caregivers }\end{array}$ & $\begin{array}{l}\text { - Diagnosis of SCLC or NSCLC; people receiving } \\
\text { hospice care at the time of enroliment were excluded } \\
\text { - Total: patients }(n=106) \text {; caregivers }(n=106) \\
\text { TSM: patients }(n=51) \text {; caregivers }(n=51) \\
\text { - Education/support: patients }(n=55) \text {; caregivers } \\
\text { (n=55) } \\
\text { - NSCLC: TSM (n=44; 86.27\%); Education/support } \\
\text { ( } n=49 ; 89.09 \%) \\
\text {-SCLC: TSM ( } n=7 ; 13.73 \%) \text {; Education/support } \\
(n=6 ; 10.91 \%)\end{array}$ & $\begin{array}{l}4 \text { sessions of telephone } \\
\text { symptom management } \\
\text { (TSM) consisting of } \\
\text { cogititive-behavioral and } \\
\text { emotion-focused therapy }\end{array}$ & $\begin{array}{l}4 \text { sessions of education/ } \\
\text { support }\end{array}$ & $\begin{array}{l}\text { Primary } \\
\text { - Patient and caregiver depressive and anxiety-Patient } \\
\text { Health Questionnaire; Generalized Anxiety Disorder scale } \\
\text { (GAD-7) } \\
\text { - Patient physical symptoms-Brief Pain Inventory } \\
\text { Short Form; Fatigue Symptom Inventory; Memorial } \\
\text { Symptom Assessment Scale (frequency and severity of } \\
\text { breathlessness and distress related to breathlessness) } \\
\text { Secondary } \\
\text { - Patients' perceived ability to manage pain, other } \\
\text { symptoms, and function \& Caregiver confidence in their } \\
\text { ability to manage symptoms }-16 \text {-item standard self- } \\
\text { efficacy scale modified from the arthritis literature } \\
\text { - Caregivers' self-efficacy to manage own emotions }-8 \\
\text { items } \\
\text { - Patient and caregiver perceived constraints on cancer- } \\
\text { related disclosure from the other dyad member-5 item } \\
\text { social constrains scale } \\
\text { - Caregiver burden -Caregiver Reaction Assessment }\end{array}$ & $\begin{array}{l}\text { - No significant group differences for } \\
\text { all patient outcomes and caregiver self- } \\
\text { efficacy for helping the patient manage } \\
\text { symptoms and caregiving burden at } \\
\text { weeks } 2 \text { and } 6 \text { post-intervention } \\
\text { - Small effects in favor of TSM regarding } \\
\text { caregiver self-efficacy for managing } \\
\text { their own emotions and perceived social } \\
\text { constraints from the patient } \\
\text { - No significant change over time for } \\
\text { study outcomes in either group }\end{array}$ & $\begin{array}{l}\text { - Findings suggest that } \\
\text { the brief telephone-based } \\
\text { psychosocial intervention } \\
\text { was not efficacious for } \\
\text { symptomatic improvement in } \\
\text { lung cancer patients and their } \\
\text { family caregivers } \\
\text { - Next steps include } \\
\text { examining specific } \\
\text { intervention components in } \\
\text { relation to study outcomes, } \\
\text { mechanisms of change, and } \\
\text { differing intervention doses } \\
\text { and modalities }\end{array}$ \\
\hline $\begin{array}{l}\text { Schofield et al. } 2013 \\
\text { (37); Australiai; ;wo-group } \\
\text { randomized controlled } \\
\text { trial; single site }\end{array}$ & $\begin{array}{l}\text { To test the effectiveness of a } \\
\text { multidisciplinary supportive } \\
\text { care program based on } \\
\text { systematic needs assessment } \\
\text { in people with inoperable lung } \\
\text { cancer }\end{array}$ & $\begin{array}{l}\text { - Diagnosis of inoperable lung or pleural (including } \\
\text { mesothelioma) cancer; scheduled to receive } \\
\text { palliative external beam radiotherapy, palliative } \\
\text { chemotherapy or radical radiotherapy and } \\
\text { chemotherapy } \\
\text { - Total ( } n=108) \text { : Intervention ( }(n=55) \text {; Control }(n=53) \\
\text { - SCLC: intervention }(n=4 ; 7.3 \%) \text {; control }(n=5 ; \\
9.4 \%) \\
\text { - NSCLC: intervention ( }(n=48 ; 87.3 \%) \text {; control ( } n=45 ; \\
\text { 84.9\%) } \\
\text { - Mesothelioma: intervention ( } n=3 ; 5.5 \%) \text {; control } \\
(n=3 ; 5.7 \%)\end{array}$ & $\begin{array}{l}2 \text { consultations at } \\
\text { treatment commencement } \\
\text { and completion and the } \\
\text { provision of a systematic } \\
\text { needs assessment } \\
\text { data to the patient's } \\
\text { multidisciplinary team } \\
\text { (MDT) }\end{array}$ & $\begin{array}{l}\text { Usual care (standard care } \\
\text { as per hospital protocol - } \\
\text { multidisciplinary meetings } \\
\text { with referrals to allied } \\
\text { health and palliative care } \\
\text { as required; no systematic } \\
\text { assessment/management } \\
\text { patient need or systematic } \\
\text { communication of patient } \\
\text { needs) }\end{array}$ & $\begin{array}{l}\text { Primary } \\
\text { - Unmet needs-Needs Assessment for Advanced Lung } \\
\text { Cancer Patients } \\
\text { - Psychological morbidity-HADS } \\
\text { - Global distress - Distress Thermometer (DT) } \\
\text { - Health related QOL-EORTC QLQ-C30 V2.0 }\end{array}$ & $\begin{array}{l}\text { - Trial closed prematurely } \\
\text { - No significant difference for any of the } \\
\text { primary measures (all } P>0.10 \text { ) } \\
\text { - Change score analysis indicated a } \\
\text { relative benefit from the intervention for } \\
\text { unmet symptom needs at week } 8 \text { and } \\
12 \text { post-assessment (effect size }=0.55 \\
\text { and } 0.40 \text {, respectively) }\end{array}$ & $\begin{array}{l}\text { Novel approach, but } \\
\text { the hypothesis that the } \\
\text { intervention would benefit } \\
\text { perceived unmet needs, } \\
\text { psychological morbidity, } \\
\text { distress and health-related } \\
\text { quality of life was not } \\
\text { supported overall }\end{array}$ \\
\hline
\end{tabular}


Table S3 TIDieR table describing early palliative care interventions

\begin{tabular}{|c|c|c|c|c|c|c|c|c|}
\hline Author, year & Intervention & Who provided & How & Where & When/how much & Tailoring & Modification & Fidelity \\
\hline $\begin{array}{l}\text { El-Jawahri } \\
\text { et al. } 2017 \\
\text { (28) }\end{array}$ & $\begin{array}{l}\text { Patients assigned to early palliative care met with board } \\
\text { certified palliative care physician or advance practice } \\
\text { nurse }\end{array}$ & $\begin{array}{l}\text { Certified palliative care physician or } \\
\text { advance practice nurse }\end{array}$ & $\begin{array}{l}\text { Face to face, } \\
\text { or over the } \\
\text { phone }\end{array}$ & In clinic & $\begin{array}{l}\text { Within } 4 \text { weeks of patient enrolment, } \\
\text { and at least monthly palliative care } \\
\text { visits until death }\end{array}$ & Not available & Not available & $\begin{array}{l}\text { (I) } 229 \text { and } 183 \text { caregivers completed the week } 12 \\
\text { and week } 24 \text { assessments with a missing data rate of } \\
16.7 \% \text { and } 33.5 \% \text {, respectively. (II) Intervention: } 110 / 137 \\
\text { caregivers completed } 12 \text { week follow up assessment; } \\
89 / 110 \text { completed } 24 \text { week follow-up assessment. (III) } \\
\text { Control: } 119 / 138 \text { caregivers completed } 12 \text {-week follow } \\
\text { up assessment, } 94 / 119 \text { completed } 24 \text { week follow-up } \\
\text { assessment }\end{array}$ \\
\hline $\begin{array}{l}\text { Groenvold } \\
\text { et al. } 2017 \\
\text { (29) }\end{array}$ & $\begin{array}{l}\text { 'Early specialist palliative care' was defined as 'usual } \\
\text { specialist palliative care' initiated at earlier time than } \\
\text { otherwise. Patients in the intervention group were referred } \\
\text { to a specialist palliative care team }\end{array}$ & $\begin{array}{l}\text { Specialist palliative care teams } \\
\text { depended on the different specialized } \\
\text { palliative care centers in the study. } \\
\text { Members included doctors, nurses, } \\
\text { physiotherapist, psychologists, social } \\
\text { workers, chaplains, secretary, and } \\
\text { volunteers, or pharmacists }\end{array}$ & $\begin{array}{l}\text { Face-to-face } \\
\text { or over the } \\
\text { phone }\end{array}$ & In clinic & $\begin{array}{l}\text { Frequency was tailored to patient } \\
\text { need }\end{array}$ & $\begin{array}{l}\text { Primary outcome was tailored to the } \\
\text { patient by being the patient's most } \\
\text { pronounced symptom/problem ('primary } \\
\text { need'); number and frequency of contacts } \\
\text { with the specialist palliative care team and } \\
\text { the treatments and other interventions } \\
\text { were determined by the patient's needs }\end{array}$ & Not available & $\begin{array}{l}\text { (I) Intervention: } 138 / 145 \text { received allocated intervention; } \\
32 \text { were lost to follow up (15 died, } 9 \text { did not answer } \\
\text { questionnaire, } 8 \text { due to administrative failure). (II) Control: } \\
139 / 152 \text { received the allocated intervention; } 93 \text { were lost to } \\
\text { follow up (15 died, } 20 \text { did not answer questionnaire, } 4 \text { due } \\
\text { to administrative failure) }\end{array}$ \\
\hline $\begin{array}{l}\text { Temel et al. } \\
2017 \text { (27) }\end{array}$ & $\begin{array}{l}\text { Patients assigned to early palliative care met with board } \\
\text { certified Palliative care physician or advance practice } \\
\text { nurse }\end{array}$ & $\begin{array}{l}\text { Certified palliative care physician or } \\
\text { Advance practice nurse }\end{array}$ & $\begin{array}{l}\text { Face to face, } \\
\text { or over the } \\
\text { phone }\end{array}$ & In clinic & $\begin{array}{l}\text { Within } 4 \text { weeks of patient enrolment, } \\
\text { and at least monthly palliative care } \\
\text { visits until death }\end{array}$ & Not available & Not available & $\begin{array}{l}\text { (I) Intervention: } 148 / 175 \text { patients completed } 12 \text { week } \\
\text { assessment; } 118 / 148 \text { completed } 24 \text { week assessment. } \\
\text { (II) Control: 153/175 patients completed } 12 \text { assessment; } \\
\text { 125/153 completed } 24 \text { week assessment }\end{array}$ \\
\hline $\begin{array}{l}\text { Bakitas et al. } \\
2015(30)\end{array}$ & $\begin{array}{l}\text { ENABLE (Educate, Nurture, Advise, Before Life Ends) } \\
\text { includes initial in-person, standardized outpatient } \\
\text { palliative care consultation by a board-certified palliative } \\
\text { care clinician and structured telephone coaching sessions } \\
\text { by an APN using a manualized curriculum }\end{array}$ & $\begin{array}{l}\text { Palliative care consultation was } \\
\text { conducted by a board certified palliative } \\
\text { care clinician; telephone coaching was } \\
\text { conducted by advance practice nurses }\end{array}$ & $\begin{array}{l}\text { Face-to- } \\
\text { face palliative } \\
\text { care visits; } \\
\text { telephone } \\
\text { coaching } \\
\text { sessions }\end{array}$ & In clinic & $\begin{array}{l}\text { Early group: within } 30 \text { to } 60 \text { days } \\
\text { of being informed of an advanced } \\
\text { cancer diagnosis, cancer recurrence, } \\
\text { or profession, in the opinion of the } \\
\text { oncologist, prognosis between } 6 \text { and } \\
24 \text { months. Delated group: patients } \\
\text { were referred to first palliative care } \\
\text { visit } 3 \text { months later }\end{array}$ & Not available & Not available & 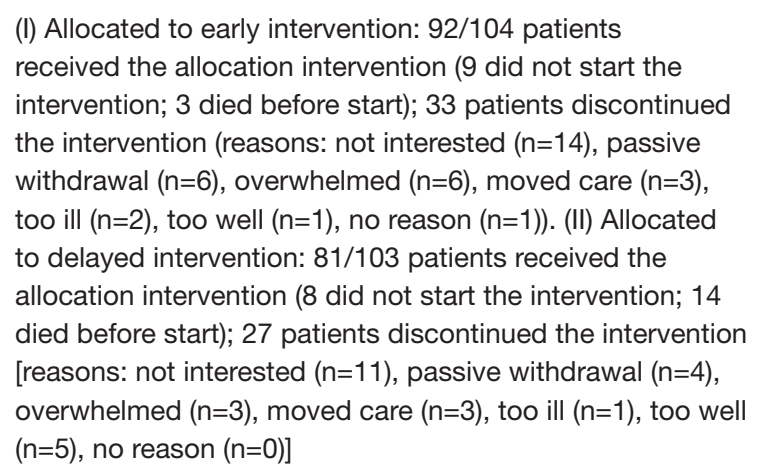 \\
\hline $\begin{array}{l}\text { Dionne- } \\
\text { Odom et al. } \\
2015(31)\end{array}$ & $\begin{array}{l}\text { ENABLE includes initial in-person, standardized } \\
\text { outpatient PC consultation and structured telephone } \\
\text { coaching sessions designed for caregivers. Caregivers } \\
\text { were encouraged to be present the in-person palliative } \\
\text { care consultation }\end{array}$ & $\begin{array}{l}\text { Consultations by a board-certified } \\
\text { palliative care physician; coaching } \\
\text { sessions delivered by advanced practice } \\
\text { nurses }\end{array}$ & $\begin{array}{l}\text { Face-to- } \\
\text { face palliative } \\
\text { care visits; } \\
\text { telephone } \\
\text { coaching } \\
\text { sessions }\end{array}$ & $\begin{array}{l}\text { In clinic or } \\
\text { over the } \\
\text { phone }\end{array}$ & $\begin{array}{l}\text { (I) Early group: within } 30 \text { to } 60 \text { days } \\
\text { of being informed of an advanced } \\
\text { cancer diagnosis, cancer recurrence, } \\
\text { or profession, in the opinion of the } \\
\text { oncologist, prognosis between } 6 \\
\text { and } 24 \text { months. (III) Delayed group: } \\
3 \text { months later. (III) Three caregiver } \\
\text { educational sessions, once a week, } \\
\text { delivered by nurses }\end{array}$ & Not available & Not available & $\begin{array}{l}\text { (l) Early group: } 61 / 63 \text { enrolled caregivers provided data for } \\
\text { analysis. } 27 \text { patients died with an enrolled caregiver. (II) } \\
\text { Delayed group: all enrolled caregivers provided data, } 39 \\
\text { patients died with an enrolled caregiver }\end{array}$ \\
\hline $\begin{array}{l}\text { McCorkle } \\
\text { et al. } 2015 \\
\text { (26) }\end{array}$ & $\begin{array}{l}\text { 10-week standardized intervention which included } \\
\text { monitoring patients' status, providing symptom } \\
\text { management, executing complex care procedures, } \\
\text { teaching patients and family caregivers, clarifying the } \\
\text { illness experience, coordinating care, responding to the } \\
\text { family, enhancing QOL, and collaborating with other } \\
\text { providers }\end{array}$ & $\begin{array}{l}\text { Clinic advance practice nurses } \\
\text { contacted patients, and trained } \\
\text { physician assistants and medical social } \\
\text { workers to be part of multidisciplinary } \\
\text { team }\end{array}$ & $\begin{array}{l}\text { Face-to-face, } \\
\text { or over the } \\
\text { phone }\end{array}$ & In clinic & $\begin{array}{l}\text { Clinic advance practice nurses } \\
\text { initially contacted patients within } 24 \\
\text { hours, and weekly phone and in- } \\
\text { person contacts were scheduled (five } \\
\text { clinic visits and five telephone calls } \\
\text { in totall) }\end{array}$ & Not available & Not available & $\begin{array}{l}\text { (I) Fidelity was assessed and monitored by the study } \\
\text { advance practice nurse coordinator through quantification } \\
\text { of whether the scheduled patient contacts occurred } \\
\text { according to the protocol's timeframe and review of } \\
10 \% \text { of the documentation by the team members to } \\
\text { ensure compliance with study protocols. (II) Intervention: } \\
54 / 66 \text { completed one-month follow-wup assessment; } \\
36 / 54 \text { completed three-month follow-up assessment. (III) } \\
\text { Control: } 68 / 80 \text { patients completed one-month follow-up } \\
\text { assessment; } 54 / 66 \text { patients completed three-month follow- } \\
\text { up assessment }\end{array}$ \\
\hline $\begin{array}{l}\text { Temel et al. } \\
2010 \text { (13) }\end{array}$ & $\begin{array}{l}\text { Patients assigned to early palliative care met with a } \\
\text { member of the palliative care team within } 3 \text { weeks of } \\
\text { enrolment and at least monthly thereafter until death }\end{array}$ & $\begin{array}{l}\text { Board certified palliative care physicians } \\
\text { and advance practice nurses }\end{array}$ & $\begin{array}{l}\text { Face-to-face } \\
\text { visits }\end{array}$ & In clinics & $\begin{array}{l}\text { Within } 3 \text { weeks after enrolment and } \\
\text { at least monthly thereafter in the } \\
\text { outpatient setting until death }\end{array}$ & $\begin{array}{l}\text { Additional visits with the palliative care service } \\
\text { were scheduled at the discretion of the } \\
\text { patient, oncologist, or palliative care provider }\end{array}$ & Not available & $\begin{array}{l}\text { All the patients assigned to early palliative care, except for } \\
\text { one patient who died within } 2 \text { weeks after enrolment, had } \\
\text { at least one visit with the palliative care service by week } 12\end{array}$ \\
\hline
\end{tabular}

